\title{
Nazionalismi: teorie, pratiche, istruzioni per l'uso
}

\author{
a cura di Stefano Bottoni*
}

Siniša Malešević

Grounded Nationalisms.

A Sociological Analysis

Cambridge UP, Cambridge 2019,

pp. 312

Gli studi sociologici sul nazionalismo come fenomeno globale del mondo contemporaneo soffrono spesso della difficoltà di conciliare le ambizioni teoriche e l'ansia della comparazione con l'analisi delle specificità storiche, geografiche e culturali dei singoli casi di studio. Il volume di Malešević, professore di sociologia allo University College di Dublino e allievo di Ernest Gellner negli anni '90, agli albori della Central European University di marca praghese, costituisce un formidabile antidoto al rischio di un sapere parcellizzato in compartimenti stagni. L'A. ha raccolto in questo volume, in forma riveduta e corretta, 11 saggi già apparsi in riviste o in opere collettanee. Non ha preteso di offrire un'interpretazione nuova del fenomeno nazionalista ma, attraverso una densa introduzione (pp. 1-20) e una rilettura riflessiva dei propri contributi precedenti, ha piuttosto collocato il proprio percorso di ricerca e studio in una cornice interpretativa unitaria: quella dei grounded nationalisms. Malešević costru- isce una teoria generale del funzionamento e delle dinamiche sociali del fenomeno nazionalista nell'era moderna a partire da due casi di studio a lui familiari per ragioni biografiche e professionali: il conflitto irlandese e i processi di costruzione, decostruzione e ricostruzione nazionale nei Balcani post-ottomani. Partendo da una solida conoscenza dell'immensa letteratura sul nazionalismo contemporaneo, l'A. combina teoria sociologica e analisi storica e offre un esempio di autentica ricerca interdisciplinare.

Secondo Malešević, l'essenza del nazionalismo non sta in una sua presunta «abnormalità storica e irritazione temporale» ma nell'essere «la forma dominante della soggettività moderna» (p. 3) in quando figlio e prodotto dell'Illuminismo occidentale. Il nazionalismo non è un'ideologia «gracile» o «sottile» ma piuttosto un impasto assai ricco e differenziato di idee, principi e pratiche che fanno integralmente parte dell'organizzazione della vita quotidiana nel mondo moderno. Da ciò consegue che il nazionalismo non debba necessariamente essere visto e giudicato come retrogrado in chiave storica né primitivo dal punto di vista dell'elaborazione intellettuale. È inoltre concettualmente fuorviante legare

* Dipartimento Sagas, via s. Gallo 10, 50129 Firenze; stefano.bottoni@unifi.it 
il nazionalismo moderno al XIX secolo in quanto «il nazionalismo come fenomeno sociologico di portata mondiale acquista significato proprio nella nostra era» (p. 4). Tutte le recenti indagini sociologiche condotte a livello globale evidenziano infatti un'identificazione sociale, mai sperimentata in altre epoche su questa scala, con la propria nationhood, ovvero un'appartenenza nazionale identificata come tale dal soggetto rispondente.

L'A. si mostra consapevole che l'intensità di tale sentimento possa notevolmente variare contestualmente alle dinamiche storiche e a una lunga serie di fattori politici, sociali e culturali. Ma il contesto organizzativo e ideologico nei quali le idee e le pratiche del nazionalismo moderno vengono sviluppate resta assai più stabile. Nel nostro mondo lo Stato nazionale è ormai l'unica forma legittima di dominio territoriale e, laddove il nazionalismo è l'ideologia "operativa" dominante, è praticamente impossibile sfuggire da una comprensione della realtà sociale svincolata dalla dimensione nazionale e dalle pratiche nazionaliste (p. 5). E su questo non influisce né l'intensità del sentimento veicolato, né la sua declinazione in termini più $\mathrm{o}$ meno inclusivi (o per usare la terminologia introdotta da Hans Kohn negli anni '40, «civici») o esclusivi («etnici»). Il nazionalismo informa la modernità in quando trascende le precedenti forme di legittimità invocate dai detentori del potere (mitologie religiose o laiche, missioni civilizzatrici tipiche dei grandi imperi coloniali). Il nazionalismo è connaturato alla modernità e se dal lato ideologico la dottrina emerge solo a ritmi intermittenti, la sua dominanza pratica persiste sia rispetto alle altre ideologie, sia rispetto ai cambi di regime o sistema.

Malešević dissente dall'interpretazione di coloro che vedono il ritorno di fiamma dell'identitarismo nativista (new nationalism) a livello globale, che rischia di schiacciare l'interpretazione del fenomeno sul presente, trascurandone la dimensione storica di lungo periodo. Come nota acutamente, il problema dell'accezione «neonazionalismo» è che nell'ultimo secolo è già stato utilizzato in vari contesti: dall'idea di un forte governo federale enunciata dal presidente americano Theodore Roosevelt al principio di autodeterminazione di Woodrow Wilson fatto proprio da Lenin con lo Stato sovietico; dai movimenti anti- e postcoloniali fino ai separatismi europeo-occidentali degli anni '70 e '80 e alle guerre di successione jugoslava degli anni '90. In definitiva, il primo errore prospettico è di considerare il nazionalismo come un fenomeno transitorio governato da poche cause contingenti, destinato ad affievolirsi o addirittura evaporare, invece di analizzarne le trasformazioni e il funzionamento nel lungo periodo.

Il secondo errore prospettico risiede nell'immaginare una tabula rasa precedente all'emergere del «neonazionalismo». Appare più produttivo studiare quest'ultimo come una particolare variante dei processi sociali in atto negli ultimi due secoli. Seguendo il maestro Gellner, l'A. parte dal presupposto che nel mondo contemporaneo la nazionalità sia così epistemologicamente normalizzata che l'appartenenza degli esseri umani a una qualche comunità identificabile come "nazionale" possa essere data per scontata. Questo è conseguenza diretta dell'evoluzione, con la mediazione di potenti movimenti intellettuali come l'Illuminismo e il Romanticismo, da una realtà premoderna in cui l'identificazione individuale passava per la dimensione locale (un villaggio, una città) o attraverso pratiche e riti religiosi. Il nazionalismo diviene così «la cornice cognitiva dominante per la comprensione di più ampie relazioni sociali», la «forma dominante della soggettività collettiva» (p. 7). Paradossalmente ma non troppo, è quindi proprio nei secoli 
della globalizzazione che il nazionalismo può maggiormente radicarsi nelle istituzioni dello Stato moderno, dal sistema educativo ai mass media, dal settore della sicurezza alla funzione pubblica. Questo nazionalismo funzionale emerge come un «fenomeno storicamente determinato e in continua evoluzione», definito dalla sua «capacità organizzativa, dall'attitudine ad articolare narrazioni ideologiche allettanti a livello popolare» e dalla sua «abilità a collegare progetti ideologici più estesi con l'universo emotivo e morale dell'interazione personale». In altre parole, il nazionalismo è «un processo, integrato dal punto di vista organizzativo e ideologico, che ha dimostrato nel corso della storia la sua capacità di penetrare il microcosmo della vita quotidiana» (p. 8). Non un'anomalia bizzarra, ma piuttosto la base dell'ordine sociale del mondo moderno.

Perché Malešević parla di grounded nationalisms e come articola tale concetto? Il sociologo di origine serba ritiene il nazionalismo storicamente fondato (grounded) poiché esso si è diffuso nelle più diverse direzioni partendo da un'elaborazione intellettuale alla quale si affiancò gradualmente una penetrazione politica nei più diversi strati sociali. Questa espansione graduale, di tipo verticale fu seguita a breve da un arricchimento più "orizzontale" quando le idee e le pratiche nazionaliste iniziarono a diffondersi per il globo. Accapigliarsi intorno all'origine geografica del fenomeno (se in Europa o nelle Americhe) è meno importante rispetto alla capacità di analizzare come idee quali sovranità popolare, indipendenza nazionale e omogeneità culturale interclassista abbiano iniziato a circolare in modo sempre più capillare nella cultura "alta" e poi in quella popolare.

L'espressione grounded potrebbe evocare suggestioni legate all'inevitabilità della diffusione del nazionalismo. L'A. chiarisce tuttavia di considerare il nazionalismo moderno un fenomeno con- tingente $\mathrm{e}$ - dato ancora più importante - «incapsulato per tutto l'800 e il primo scorcio del '900 in altri progetti ideologici, quali il liberalismo, il socialismo, il femminismo, l'imperialismo, il conservatorismo e il razzismo, per citarne solo alcuni» (p. 9). Solo dall'inizio del '900 l'espansione sociale del fenomeno dalla classe media al proletariato industriale e poi alla società contadina restrinse l'orizzonte del nazionalismo a correnti di destra (imperialismo, colonialismo, monarchismo, fascismo, eugenetica). Con il collasso degli imperi multietnici e delle strutture coloniali, il paradigma dello Stato nazionale si affermò saldamente come l'unica forma legittima di organizzazione della politica. Il fondamento storico trasformò il nazionalismo in una forza sociale potente e persistente, che si sviluppava ed espandeva insieme alla crescita delle capacità logistiche e ideologiche degli attori statali e non.

In secondo luogo il nazionalismo è radicato sul piano organizzativo, con un rimando obbligato al passaggio dalle società rivoluzionarie segrete dalla struttura alveolare come la Carboneria italiana ai grandi movimenti di massa come la Gaelic Athletic Association irlandese o le associazioni sportive dell'Europa centro-orientale asburgica. Nelle fasi di transizione tardo- e post-imperiale, la diffusione e il successo del messaggio nazionalista dipesero molto dalla capacità di organizzare raduni di massa, scioperi, petizioni, competizioni culturali e sportive intese a stimolare una comprensione nation-centric della situazione politica e sociale. Anche successivamente, la creazione di istituzioni parallele a quelle nazionali/imperiali degli occupanti, gli scioperi, boicottaggi e forme di violenza organizzata (guerriglia, terrorismo) richiesero una crescente maturità logistica da parte delle forze nazionaliste. Ma come aveva già osservato George Mosse, lo stesso Stato nazionale negli 
ultimi due secoli ha enormemente aumentato la sua capacità amministrativa e il controllo del territorio attraverso la creazione e il perfezionamento di apparati amministrativi, giuridici, militari e di polizia che lo rendessero in grado di controllare e monitorare la popolazione senza esercitare un uso sistematico della violenza. Lo Stato nazionale costituì il principale strumento del fenomeno attraverso una panoplia di mezzi, fra $\mathrm{i}$ quali spiccavano quelli coercitivi, in quanto il nazionalismo divenuto istituzione statale forgiava unità nazionale a spese dei particolarismi locali, come mostrò la campagna anti-vandeana dei giacobini francesi o la spietata battaglia dei coloni americani contro i nativi. Non vi è dunque da stupirsi che l'omogeneizzazione etnoculturale (e in ultima istanza nazionale sia stata ottenuta, non solo in Europa ma a livello globale, attraverso pratiche coercitive e violenza fisica. Il processo di nazionalizzazione inteso come standardizzazione culturale ed emancipazione civile va infatti inteso come un letto di Procuste. Lo Stato richiedeva ai cittadini un «sostanziale grado di uniformità culturale» e nessuna entità nazionale poteva «rinunciare allo sforzo organizzativo mirato alla standardizzazione. Il radicamento organizzativo svolse un ruolo centrale nella nascita, crescita, trasformazione ed espansione dei nazionalismi» (p. 11).

In terzo luogo il nazionalismo si è radicato nel nostro mondo sul piano ideologico. Dalle ideologie nazionaliste emana ogni visione utopica e mitopoiesi legata alla liberazione dal giogo imperiale straniero, alla sovranità popolare e all'emancipazione collettiva. Secondo i nazionalisti, ogni nazione avrebbe diritto a un proprio Stato cui ogni cittadino possa prestare fedeltà. I nazionalisti riconoscono altri tipi di identità sociale ma affermano la preminenza assoluta dell'attaccamento alla propria nazione, come già riconosciuto da teorici come
Elie Kedourie e Anthony J. Smith. Ma il nazionalismo è ideologicamente radicato anche nel senso che fornisce una giustificazione popolare a un particolare tipo di azione. «I codici ideologici nazionalisti operano spesso in modo simile all'algoritmo di programmazione - flessibile nell'identificare nuove soluzioni e nuove risposte ai problemi specifici senza che queste soluzioni si debbano discostare dai sistemi già consolidati, ovvero l'universo basato sulle nazioni» (p. 13).

In quarto luogo, il moderno nazionalismo dipende molto dal radicamento micro-interazionale. Il nazionalismo si costruisce in modo discorsivo attraverso interazioni personalizzate e quotidiane. Anthony P. Cohen parla in proposito di un «nazionalismo personale» che si rivolge all'individuo e fornisce «un senso di sicurezza ontologica ai singoli» (p. 14). Uno degli elementi più innovativi del volume, tanto nelle premesse metodologiche quanto nella dimostrazione empirica, sta proprio nell'analisi di come le organizzazioni sociali legate all'idea della nazione penetrano nel microcosmo delle interazioni quotidiane. L'ideologia nazionalista descritta da Malešević mostra un chiaro intento egemonico sin dal XIX secolo. Dichiara di parlare la lingua della coesione (micro)comunitaria ma punta esplicitamente alla cancellazione delle diversità etno-culturali. Analizzato da questo punto di vista, il «neonazionalismo» transatlantico degli ultimi decenni non rappresenta affatto un nuovo attacco alla pluralità culturale quanto una persistenza ostinata e logica dello stesso fenomeno già osservato negli ultimi due secoli: un tentativo organizzativo e ideologico di forgiare e mantenere l'unità nazionale negando le diversità. La principale differenza fra il nazionalismo storicizzato e quello attuale risiede nell'identità del bersaglio polemico: nel passato le microidentità locali, oggi gli immigrati e il "meticciato" multiculturale combattuto dai nativisti. 
I capitoli empirici del volume collocano importanti elementi del dibattito scientifico contemporaneo nella cornice interpretativa descritta sinora. La discussione del rapporto fra imperi e Stati nazionali (capp. 3-4) e fra "piccole" e "grandi" nazioni (cap. 5) è preceduta da una fine analisi della genesi delle pratiche del moderno nazionalismo (capp. 1-2). Partendo dal riconoscimento che il concetto di nazione si espone facilmente al rischio di reificazione in quanto concettualmente ambiguo e polisemantico, l'A. segue Benedict Anderson nel sostenere che indipendentemente dalle loro dimensioni le nazioni sono sempre «immaginate come limitate in termini di popolazione e territorio entro confini definitivi sebbene elastici, oltre i quali stanno altre nazioni», in quanto a differenza degli imperi «nessuna nazione si immagina confinante con l'umanità» (p. 26). Per comprendere le origini sociali della nozione di «identità nazionale» è dunque fondamentale concentrare l'attenzione sui tre processi storici che hanno reso l'identità nazionale paradigmatica nel mondo contemporaneo: ideologizzazione centrifuga, burocratizzazione cumulativa della coercizione e avvolgimento della microsolidarietà. L'ideologizzazione centrifuga viene definita come un fenomeno storico strutturale e su larga scala attraverso il quale organizzazioni sociali quali i movimenti nazionalisti progettano e riescono a forgiare, quantomeno temporaneamente, un certo grado di unità ideologica superando le diversità insite in entità così estese e frammentate.

È dunque il nazionalismo come specifico processo ideologico a generare identità nazionali più $\mathrm{o}$ meno condivise e non il contrario (pp. 31-32). La definizione di burocratizzazione cumulativa del potere coercitivo viene mutuata da Michael Mann e raffigura la panoplia di mezzi e strumenti che rendono gli Stati nazionali moderni in grado, in modo assai più efficace e capillare rispetto agli imperi premoderni e alle monarchie medievali, di controllare il territorio, la popolazione, i movimenti sociali. L'accelerazione impressa a questo processo plurimillenario dagli ultimi duecentocinquant'anni sarebbe strettamente correlata alla proliferazione dello Stato nazionale come modello dominante di organizzazione territoriale. La compenetrazione dei tre elementi citati (ideologia, organizzazione, microsolidarietà) è così stretta da spingere l'A. a legare a essi la sussistenza di un'identità nazionale collettiva (p. 39).

Nei capitoli centrali (pp. 70-134), dedicati all'analisi storico-sociologica della transizione dagli imperi multietnici agli stati nazionali, il volume offre un'analisi empirica della diffusione del fenomeno nazionalista. Malešević contesta la diffusa visione di un'antinomia fra imperi e nazioni e traccia un parallelo fra pratiche nazionali e imperiali basato su tre fattori: burocratizzazione cumulativa della coercizione, ideologizzazione centrifuga e appropriazione delle reti della microsolidarietà. Il nazionalismo post-imperiale degli Stati nazionali ibrida gerarchie formali e interazione locale basata sull'informalità. Riesce dove gli imperi multietnici avevano fallito: riconcilia pubblico e privato, dimensione macro e micro. Dalla solidarietà verticale dell'impero emerge quella orizzontale della nazione. Il nazionalismo è potente proprio in quanto «si radica nelle reti della più genuina microsolidarietà di gruppo» (pp. 84-85). Dall'analisi comparata e diacronica delle strategie politiche e sociali degli imperi dell'antichità (da quello romano a quello cinese, definiti sulla scorta di John Breuilly capstone empires, strutture dispotiche che si impongono sulle periferie) e delle nazioni "imperiali" dell'Europa contemporanea emerge un rapporto fra impero e nazione per nulla conflittuale, e anzi a tratti simbiotico, quantomeno fino al sopravvento del nazionalismo moderno, frutto non di 
processi irreversibili o inevitabili ma di cicli storici di sviluppo.

Il capitolo 5 (pp. 111-34) allarga ulteriormente il discorso al problema storico delle "piccole nazioni" attraverso il confronto fra l'Irlanda e il nation-building di alcune nazioni balcaniche (Grecia, Serbia e Bulgaria). Sebbene si tratti in entrambi i casi di un nazionalismo antimperiale - britannico, ottomano o asburgico -, dall'analisi delle strategie nazionaliste perseguite dalla seconda metà dell' 800 emerge una differenza importante in merito al dilemma della "taglia" della nazione. La fiera consapevolezza dell'inferiorità numerica e organizzativa di fronte al nemico imperiale si rivelò una potente arma ideologica per gli irlandesi, mentre i nazionalismi balcanici tesero sempre a nascondere o negare le proprie evidenti debolezze strutturali (p. 133). Si tratta dunque di strategie nazionaliste divergenti ma accomunate da un argomento morale a favore della propria sovranità.

Nella seconda parte del volume spicca, per densità concettuale e acutezza di analisi, il cap. 7 sul rapporto fra nazionalismo e guerra nei Balcani contemporanei. L'A., riprendendo pur senza citarla l'importante ricerca di Max Bergholz sul ruolo della violenza nella trasformazione in senso "etnico" delle microcomunità rurali (Violence as a Generative Force: Identity, Nationalism, and Memory in a Balkan Community, 2016), sottolinea che non fu il presunto e innato "nazionalismo" delle popolazioni locali a stimolare la violenza etnica. Al contrario, banditismo e microconflitti sociali intercomunitari generarono una spirale di violenza che trovò una cornice interpretativa unitaria nel sentimento nazionalista.

Nel capitolo 10, dedicato al nesso fra globalizzazione e soggettività nazionalista, Malešević esplora invece il terreno della contemporaneità più stretta $\mathrm{e}$ in polemica con i teorici della modernizzazione riflessiva (da Anthony Gid- dens a Ulrich Beck) evidenzia l'errore prospettico di chi credeva che un mondo globalizzato avrebbe relegato il nazionalismo ai margini delle vicende umane. Nei fatti, la globalizzazione economica e politica non si è rivelata affatto incompatibile con il progetto nazionalista nel mondo occidentale e, in misura ancora più estrema, nell'ambito dei vecchi/nuovi progetti statual-imperiali (Cina, Russia, Turchia). La guerra fredda e il progetto occidentale postbellico di democrazia modellata sullo Stato nazionale si sono rivelati decisivi, pur in un contesto di pace prolungata, per la nazionalizzazione delle masse (pp. 239-41). Le democrazie liberali più avanzate, ammonisce l'A., perseguono inoltre progetti nazionalisti pur senza sbandierarlo. Il caso danese o finlandese mostra che un nazionalismo apparentemente blando, strettamente controllato da valori liberali, si rivela all'atto pratico molto più efficace sul piano delle politiche pubbliche rispetto ai nazionalismi aggressivi imposti dalle élite autoritarie (Corea del Nord ed Eritrea, entrambi richiamati da Malešević, ma si potrebbero aggiungere gli stati "falliti" delle periferie sud-orientali europee e le autocrazie dell'Asia centrale).

Proprio sul rapporto fra globalizzazione e soggettività nazionaliste l'A. lancia un ammonimento il cui messaggio pervade l'intero volume: il cosmopolitismo inteso come Weltanschauung rimane patrimonio di una comunità minoritaria e largamente intellettuale, caratterizzata da elitismo e privilegio sociale (p. 247). Non mette quindi a rischio le posizioni consolidate del nazionalismo, né le sue prospettive future di ascesa e integrazione nelle ideologie del mondo che verrà. Il nazionalismo è un fenomeno strutturale, saldamente radicato nella psicologia individuale e collettiva, e nessuna utopia universalistica riuscirà mai a sradicarlo. Piuttosto che combatterlo senza conoscerlo, meglio 
dunque esplorarne i meccanismi di funzionamento, come ci invita a fare questo libro provocatorio e stimolante.

\section{Stefano Bottoni}

\section{Florian Bieber \\ Debating Nationalism. The Global Spread of Nations Bloomsbury Academic, London-New York 2020, pp. 246}

Il nazionalismo è uno di quei fenomeni della modernità caratterizzati da una forte influenza nello spazio pubblico, che si può periodicamente allentare per poi ritornare puntuale con una carica di violenza simbolica, e spesso anche materiale, tale da suscitare l'attenzione della comunità scientifica. Bieber, politologo di origine lussemburghese formatosi a Graz, ricostruisce la genesi storica e politica dello Stato nazionale inquadrandolo dalla prospettiva dell'ideologia nazionalista, sua forza creatrice, fonte e motore dei movimenti nazionali in tutto il mondo. L'A. intende ricondurre i tratti fondamentali del dibattito contemporaneo alle forme in cui il nazionalismo emerge e riemerge nei discorsi e nelle narrazioni delle élite politiche, accademiche e intellettuali. Il nazionalismo trasforma l'ordine politico e sociale tradizionale forgiandone uno moderno, ovvero il nostro mondo, quello della modernità riflessiva intesa nella sua immensa complessità. Mentre evidenzia un'ascesa del nazionalismo multiforme a livello globale in seguito alla fine della guerra fredda, l'A. interpreta questi eventi non come la comparsa di un «nuovo nazionalismo», ma piuttosto come il segno di una sua presenza ancora più pronunciata nella vita pubblica in forme virulenti ed esclusive (pp. 190 e 197).

Bieber si è formato come studioso del nazionalismo osservando e studiando le guerre jugoslave (1991-1999), un fenome- no ancora non del tutto esaurito. I movimenti etnonazionalisti, il ruolo delle élite nazionali, le identità etniche costruite con strumenti di inclusione ed esclusione coercitiva imposti alla gente comune come camicie di forza, hanno costituito le tematiche dei suoi studi dedicati allo spazio ex jugoslavo e all'Europa sud orientale. La complessa costruzione delle identità collettive etnonazionali fu resa possibile dalla strumentalizzazione degli elementi distintivi della lingua, della religione, della stirpe, del mito delle origini, lungo le linee delle similitudini, forzando la capacità immaginativa delle collettività, per giustificare e approfondire i confini tra i gruppi e innalzare fra essi barriere invalicabili. L'uso dei dispositivi criminali legittimati dal traguardo di una costruzione statale di tipo etnonazionalista, documentato dagli archivi e dalle sentenze del Tribunale penale internazionale per l'ex-Jugoslavia (Tpij), aveva rivelato la natura contingente e discrezionale del nazionalismo in quanto tale, soprattutto nei casi in cui il "clustering geografico" di una collettività non corrispondeva al principio di congruenza tra la dimensione territoriale e quella (etno)nazionale. L'A. qui parla del nazionalismo in termini di «un'ideologia malleabile e ristretta che valorizza l'appartenenza a una nazione più dell'appartenenza ad altri gruppi» (p. 10).

In questo volume Bieber crea una cornice più ampia per offrire la sua visione teorica a un pubblico composto prevalentemente dagli studenti universitari, cui si rivolge la collana "Debates in World History". L'A. si avvale delle lezioni apprese studiando i "Balcani" e il suo sguardo è consapevole del nazionalismo metodologico che contraddistingue i classici del '900, da Max Weber e Karl Deutsch, da Ernest Gellner e Anthony J. Smith, le cui teorie si adattano prevalentemente ai modelli di sviluppo storico occidentali quando non «distintamente Europei» (p. 34). 
Lezioni fondamentali sul nazionalismo arrivano anche da Eric J. Hobsbawm e Benedict Anderson, che cambiano la prospettiva analitica sul fenomeno. L'esigenza della chiarezza per un testo introduttivo che comprenda uno sguardo critico sul dibattito attuale, rende il volume particolarmente sensibile a quel «caos terminologico» già denunciato da Brubaker e Cooper (Beyond "Identity", 2000). Bieber introduce, di volta in volta e con molta cura, i concetti di nazione, etnia, popolo, cittadinanza, Stato nazionale e statualità, spiegando come queste nozioni interagiscono tra loro, portando ad azioni collettive determinanti nella storia delle modernità passate e presenti. Oltre all'evidente ubiquità delle nazioni, è la processualità storica nella costruzione delle nazioni moderne, ancora in atto, a rivelare come un nazionalismo virulento escluda chi ritenuto diverso. Vi è poi una dimensione graduale e temporalmente estesa, che comporta trasformazioni profonde e crea una società civile e istituzioni proprie di una convivenza democratica basate sui diritti e sull'idea di governare «for the people, by the people» (p. 35). In tal modo, sostiene l'A., si crea una dialettica fra la dimensione particolaristica ed esclusiva dell'appartenenza nazionale e quella universalistica della condivisione dei valori di base garantita dalla sovranità nazionale. Una graduale democratizzazione inclusiva della società permette, quantomeno nei paesi liberaldemocratici, la coesistenza e la cooperazione potenzialmente pacifica delle nazioni a livello globale.

Il tema del nazionalismo "buono" e di quello "cattivo" ricorre spesso nel dibattito scientifico e il volume, sebbene non ambisca a risolverlo, sottolinea che la guerra e la violenza, nelle sue diverse forme, rimangono comunque dispositivi strettamente connessi al nazionalismo, rintracciabili anche nel discorso populista che forma le recenti politiche antimigratorie (pp. 159-185 e 211). In tal senso, l'A. si sofferma sulla natura intrinsecamente politica del nazionalismo, fondato - e allo stesso tempo base - di specifiche politiche identitarie, poggiando su un presunto bisogno umano di appartenere a un «gruppo identificabile» (p. 189). Di conseguenza, un nazionalismo latente - banale e quotidiano - può essere mobilitato nelle situazioni di crisi aumentando il potere degli strumenti di identificazione al fine di discriminare in modo positivo o negativo particolari categorie di cittadini e residenti. Entrano quindi in scena altri elementi identitari quali etnia, genere, classe, religione e razza, che vengono strumentalizzati per garantire o negare la piena cittadinanza alle collettività e agli individui, trasformando i gruppi minoritari di dubbia lealtà in capri espiatori da perseguitare ed espellere (pp. 99-128 e 192).

Il testo diventa particolarmente intrigante per una lettrice informata proprio nel passaggio da un'introduzione più generale dei primi capitoli alle dimensioni del nazionalismo negli ultimi decenni. La seconda parte del volume analizza i processi di decolonizzazione e il postcolonialismo, i cosiddetti conflitti etnici, le migrazioni e le politiche della diversità, per concludere con i nuovi nazionalismi e il loro nesso con l'autoritarismo e i movimenti populisti. A ciascun tema Bieber dedica un capitolo, cercando tuttavia di tracciare un filo conduttore che reinterpreta le radici dello stato nazionale moderno, la storia del '900, definito il secolo della violenza (nazionalista), e i primi decenni del nuovo secolo.

Mi soffermo sul nesso tra nazionalismo, autoritarismo e populismo definiti dall'A. come le tre tendenze politiche globali più significative dei nostri tempi. La versatilità del nazionalismo lo ha reso una delle forze globalizzanti «senza chiare alternative», grazie alla sua capacità di strutturare le relazioni sociali e il sistema politico globale (p. 208). Allo 
stesso tempo, i processi di globalizzazione vengono percepiti dai custodi della nazione come una minaccia, sotto forma di un'alternativa cosmopolita o di identità sempre più ibride (p. 190). Allo stesso tempo secondo l'A. non è possibile riscontrare un chiaro nesso fra il nazionalismo e l'autoritarismo crescente neppure nei paesi dell'Unione europea caratterizzati da tendenze illiberali. Laddove cioè i politici populisti, soprattutto di destra, si associano facilmente al discorso identitario nazionalista, linfa di un'ideologia versatile, creando strategie di legittimazione basate sull'identità nazionale (p. 195). Sebbene l'A. evidenzi come il populismo sia presente anche a sinistra, facendo riferimento a Chantal Mouffe e alla sua analisi dei casi dei movimenti Podemos e Syriza', risulta evidente che il nesso con le narrazioni nazionalistiche sia più stretto a destra. I migranti diventano così il capro espiatorio perfetto, e in nome della loro supposta minaccia si innalzano nuovi muri e si fortificano i confini.

Senz'altro limitato dai vincoli editoriali, l'A. però tralascia alcuni punti che varrebbe la pena approfondire. Il primo riguarda il tema dell'integrazione europea. Bieber afferma che il progetto dell'unificazione degli stati nazionali europei può essere considerato, fin dagli albori, come «il più sofisticato e avanzato tentativo di contenere lo Stato nazionale» (p. 208). Ma l'Unione europea non viene quasi mai problematizzata in questa prospettiva, nonostante $\mathrm{i}$ riferimenti puntuali presenti nel volume. Una maggiore considerazione della tensione tra il sovranismo nazionalista e la dimensione politica e sociale sovra- e transnazionale inerente al progetto europeo avrebbe giovato alla coerenza interna del discorso. Il secondo tema è quello del capitalismo e della sua importanza per la configurazione poliedrica della modernità, sia nella sua versione neoliberale che in quella globalizzata. Nell'analisi del nazionalismo e dello Stato nazionale l'A. preferisce ricorrere ai termini «industrializzazione», «economia» e «spazi economici». Sarebbe interessante capire il motivo di questa scelta. Il terzo tema da approfondire riguarda il genere, per il quale si esprime un'esemplare consapevolezza di quanto a lungo gli studi sul nazionalismo abbiano ignorato questa dimensione. Ciononostante, solo il $10 \%$ degli autori citati nelle note sono donne: un'ulteriore conferma della necessità di rendere più visibili, anche in questo campo, le ricerche delle molte studiose.

Una citazione mi sembra particolarmente significativa per sottolineare la responsabilità condivisa della cittadinanza democratica riguardo le scelte del nostro futuro, affinché la violenza intrinseca a ogni forma di nazionalismo possa essere contenuta: «Nations aren't simply, but they became, are transformed, and are changed by those who claim to speak for them, by the choice of its members and others who shift boundaries» (p. 212).

Tatjana Sekulic**

\section{John Connelly \\ From Peoples into Nations. A History of Eastern Europe \\ Princeton UP, Princeton 2020, pp. 956}

From Peoples into Nations is an extensive survey of the history of Eastern Europe from the end of the $18^{\text {th }}$ century to today. Connelly is one of the most respected American historians in the field, so this book is destined to become

* Dipartimento di sociologia e ricerca sociale, via Bicocca degli Arcimboldi 8, 20126 Milano; tanja.sekulic@unimib.it 
one of the standard texts in universities all over the world. However, substantive discussion of this book is unlikely, given the scale of the work and the extensive time frame it covers. It is an unwieldly book, much like Tony Judt's Postwar. This means that students are unlikely to read it in its entirety, and professional historians will be disinclined to discuss it critically. It will be consulted by scholars and students in a selective manner, on very specific topics. The only really noticeable omission of that of Greece. The author candidly remarks: «Greece... would merit inclusion for much of its history up to $1945 »$ (p. 826, n. 31). This is a disconcerting statement, concerning one of the key territories of Eastern Europe and of the Balkans in particular. The omission of the history of Albania is more understandable, since up to 1914 it requires a familiarity with Ottomanist, and not simply Balkanist research. But this would also apply to the rest of the Balkan region in the same period. There is a strong sense that the author's decisions about what to include have been unduly influenced by the publisher, and the demands of the academic market.

Connelly's approach reflects three differing chronological axes: the preCommunist phase (1770ca-1945); the Communist phase (1945-1989) and the post-Communist phase (for an informed discussion of the $19^{\text {th }}$ century dimension of the book, see G.B. Cohen, John Connelly's Long March through East European History, «Austrian History Yearbook», 2021, pp. 273-79). The first phase inevitably involves confronting the issue of nationalism. On this point the author posits himself in the camp of 'primordialism', to use the term established by Clifford Geertz, an approach which explains the rise of nationalism in terms of the expression of a pre-existing national identity. He also directly challenges the more specific approach of «national indifference» championed by Pieter Judson and Tara Zahra, who see nationalism as merely one of the options on offer.

Furthermore, Connelly argues in favour of a form of Eastern European negative exceptionalism: «no other region has witnessed such frequent, radical, and violent changing of borders to make nations fit states» (p. 3). Indeed, «the region... belongs to an experience that defies the imaginations of people in the West» (p. 26). Irish readers might have some reservations on this point. Connelly intends to display «Eastern Europe as a region with a particular sensitivity about identity, gained over generations, and because it was vested in local language, this identity was untranslatable and resisted direct communication. That is what ethnic nationalism is: having something of one's own that does not go beyond ostensible boundaries, be it the family hearth, the nation-state, or an empty picture frame» (p. 27). In most respects and together with many other authors Connelly is simply following the path outlined by Hans Kohn's dichotomy of «ethnic vs. civic» nationalisms.

In Connelly's view, «as soon as [19 ${ }^{\text {th }}$ century] patriots created national languages, nationalism itself became the language of politics, and no one who wanted power could avoid speaking it, whether they called themselves liberal, fascist, or Communist» (pp. 19-20). Indeed, «humans make their own nations, but not just as they choose. They live in communities and speak languages that they help shape but have not manufactured. Nations never began as simple figments of imagination; instead, nationalists used building blocks of existing national chronicles and tales, interpreted to be sure, but never entirely invented. They made new words but built on existing syntaxes; they used ideas popular among rural folk about who they 
were, and about who their enemy was (usually an imperial power)» (p. 21).

Connelly adds a further element: the «fear of oblivion»: «Superficially, Eastern Europe's nationalism may seem like nationalism everywhere: occasionally flaring to incandescent passion, but normally, in everyday life, just one aspect of people's sense of self, and not the most important... Yet nationalism remains a "crisis frame" of reference that politicians can appeal to when opportune, for example, in the enduring economic crisis of the 1930s, when radio stations in Germany spewed hate-filled messages to Germans living in Czechoslovakia, or during the hyperinflation that wracked Serbia in the 1980s when the banker Slobodan Milošević discovered the nationalist in himself and rose to power by resurrecting fears that Serbs faced "extinction"» (p. 24). This view also assumes that «fear of disappearance from history was unknown to nationalism in England, France, Italy, Spain, Russia, Scandinavia, and the Low Countries» (p. 788).

In reality, this «fear of oblivion», albeit being a reality in most nationalist cultures, is simply a Romantic version of what is commonly called «assimilation». In Gellner's terms, Ruritanians end up speaking Megalomanian - or vice versa: the effect is identical. Fear of extinction in the strict sense is commonly called «genocide». Nationalists tend to confuse assimilation and genocide, but most people who have visited Oświęcim are quite capable of making a distinction between assimilation and genocide. In his dispute with Geertz in the mid-1980s Ernest Gellner once depicted American culture in terms of a pendulum, oscillating between the idea that the world was, or should be, like America («The world is flat», as Thomas Friedman put it) to the idea that the world was not like America, and therefore everything should be explained in terms of cultural differ- ences (The Politics of Anthropology, «Government and Opposition», 23, 1988, n. 3, pp. 290-303). Post-Cold War America could be easily interpreted starting from that polarization.

Connelly clearly belongs to the camp of the culturalists. This leads him to the conclusion that «Contrary to what some scholars have written, the development of national identity was not something that may or may not have happened, but as close as human communities get to sharing a common fate» (p. 790). This may well be an accurate description of a nationalist faith, but it is less clear what it can mean for a historian. Nationalists of course want their people/nation to share a common fate, but not all wishes can be granted in history. «For nationalists, national rights were not one species of rights - for example, of human rights - they were the right from which all others flowed; the precondition for human freedom. István Széchenyi recognized the logic in 1845, asking: "if you want to achieve liberty, on the basis of what nationality do you hope to accomplish it? Slav or German?”» (p. 806).

Connelly sometimes stretches his historical overview too thinly. As it happens, Széchenyi devoted one of his most important studies to hard economic issues: Credit (Hitel, Pest 1830; also available in German translation). He certainly referred to nationalism, but he had a perfectly clear idea of who should direct the process of nation-building. He knew how far he wanted to go and remained a loyal subject of the Habsburg Monarchy. His more democratic opponent, Lajos Kossuth, disagreed; but he did so on the basis of a clear understanding that to be a modern nation, one needed to «possess the independent levers of civilization... trade and the manufacturing industries» (A. Janos, The Politics of Backwardness in Hungary, 1825-1945, Princeton 1982, p. 73). So Connelly argues: «the coor- 
dinates of the global story as told in Gellner's Nations and Nationalism are either irrelevant or secondary: for example, John Stuart Mills's idea that a national state had to be "feasible", or that nationalism required a particular threshold of size before it could be properly launched. Czechs or Slovenes knew nothing of such parameters and made their history without and against them»(p. 797). On the contrary, Eastern European nationalists were all too aware of these parameters.

Unsurprisingly, the real strength of Connelly's book emerges in the sections covering the Communist period (to which he devoted his Captive University: The Sovietization of East German, Czech, and Polish Higher Education, 19451956, Chapel Hill 2000). In this field, the book is not merely state of the art, but also thoughtful and balanced. The issue of «totalitarianism» is dealt with deftly and reasonably; as is the issue of returnees in post-1968 Czechoslovakia - and elsewhere, for that matter - is also dealt with appropriately, although an interesting parallel could have been drawn with Jewish return migration from the USA to Eastern Europe before 1914 (see J.D. Sarna, The Myth of No Return: Jewish Return Migration to Eastern Europe, 1881-1914, «American Jewish History», 71, 1981, n. 2, pp. 256-68).

The historical perspective begins to weaken when the author comes to the decline of Eastern European Communist systems and the final collapse in 1989. The depth of knowledge is highly impressive, but this part is really characterised by a high-level journalistic approach. It is an example of 'High Journalism', rather than historical writing. Even though many archives have been opened and combed through by a generation of researchers, the sources have not been adequately «marinated», to borrow Robert Darnton's fitting expression. The anxiety to provide a comprehensive "history of the present" prevails over the need for the historian's detachment. The more the author strives to provide an up-to-date account of all sorts of details, such as the opening of the Hungarian border in 1989, the less the overall picture is clear. The presentist bias becomes even more marked as Connelly delves into the post-Communist past. The account of the Yugoslav wars is adequate, but not outstanding. When the author reaches the period of Eastern European accessions to the expanding European Union, the picture becomes blurred and patchy. Connelly opts for the default option in facing the challenges of explaining the demise of the naïve post-1989 dreams of Western spectators, rather than of actual inhabitants of Eastern Europe. He avoids the short cut of explaining everything in terms of the overarching power of «neoliberalism». He finds the space to mention the collapse of any left-wing alternative. But he finds nothing better to say than «beginning in about 2010, we have seen that East Central Europe stubbornly carries its own past... The fact is that East Central Europe is a place where the first, second, and third worlds persist and overlap, each making claims on the same and different pasts» (p. 799).

This is not because of ignorance of developments in the region - Connelly is remarkably well informed. But because the overall framework of the book is based on Eastern European exceptionalism, he resurrects the ghost of the Linz Programme of 1882 in order to explain the current authoritarian trends (p. 775). In conclusion, this book remains important and remarkable, but highly flawed. If not the author, the publisher might well argue that for generations of students who were not even born in 1989, a conventional narrative is required. The overall framework - despite all the useful summaries of 
the most recent research - is remarkably traditional: to understand Eastern Europe you need nationalism and more nationalism. A more concise narrative and analysis would have been more useful and effective. «Less is more».

\section{Guido Franzinetti*}

\section{Francesco Berti-Filippo Focardi- Valentine Lomellini (a cura di) L'Europa dei nazionalisti. Prospettive storiche}

FrancoAngeli, Milano 2020, pp. 233

La scomparsa del nazionalismo dallo scenario politico continentale è stata predetta e annunciata in molte occasioni. Una prima volta, con la diffusione dell'internazionalismo, alla fine del XIX secolo; poi al termine della seconda guerra mondiale, con l'avvio dei processi di integrazione europea; e ancora alla fine della guerra fredda, sull'onda della globalizzazione economica. Ma il nazionalismo è un po' come l'araba fenice, ed è tornato ancora una volta al centro del dibattito scientifico e politico. L'affermazione di movimenti e partiti della destra radicale in molti paesi europei, i numerosi successi elettorali ottenuti dai nazionalismi sub-statali e la prospettiva patriottica adottata anche da alcuni movimenti di sinistra, hanno reso ancora più impellente riprendere le fila del dibattito sul nazionalismo, che in Italia è stato a lungo carente e lacunoso.

Questo volume ha proprio il merito di provare a colmare una di queste lacune, esaminando il complesso rapporto intercorso tra diversi nazionalismi e l'idea di Europa tra il XIX secolo e il 1945. Il testo, che è il risultato di un convegno internazionale di studi tenutosi nel 2019 all'Università di Padova, si articola in due sezioni tematiche, che seguono un ordine fondamentalmente cronologico: Dal XIX secolo alla Prima guerra mondiale e L'età dei totalitarismi. Est $e$ ovest a confronto. Ad aprire il volume è un interessante saggio di Marco Meriggi che evidenzia l'origine tutt'altro che conservatrice del nazionalismo, che anzi dopo la Rivoluzione francese veniva considerato un fenomeno modernizzatore e progressista, patrimonio dei nascenti movimenti democratici e repubblicani. Il nazionalismo, quindi, appare subito capace di importanti ibridazioni ideologiche e di alimentare sentimenti tanto inclusivi quanto escludenti (p. 26), e soltanto alla fine del XIX secolo, con l'affermazione dell'imperialismo e del darwinismo sociale, assunse caratteri prevalentemente conservatori, anche nel caso di quei movimenti liberal-democratici eredi della rivoluzione e dei moti del 1848. In questo senso è molto interessante il contributo di Mario Tesini, che più che sulla dimensione europea si concentra sulle fascinazioni imperialistiche dei repubblicani francesi che, dopo il grande trauma del 1870-71, elaborarono il concetto di république coloniale (p. 76).

Un'idea, quella della missione civilizzatrice delle nazioni europee, che ha permeato anche il nazionalismo italiano dagli albori del XX secolo, come spiega Antonio Varsori. Un'idea sfruttata soprattutto dal regime fascista per giustificare le proprie mire espansioniste, e che entrerà in crisi soltanto negli anni '50 quando, secondo l'A., l'integrazione comunitaria, la trasformazione socio-economica e l'affermazione di una nuova classe politica, avrebbero ridotto l'influenza del nazionalismo nella vita politica italiana (p. 74). Missione simile anche per i nazional-democratici polacchi di fine XIX secolo, convinti che spettasse proprio alla Polonia fornire un

* Dipartimento di Studi umanistici, via Galileo Ferraris 116, 13100 Vercelli; guido. franzinetti@uniupo.it 
modello per il rinascimento cristiano, anzi cattolico, di un'Europa ormai sempre più irrimediabilmente compromessa da laicismo e materialismo, come spiega Joanna Sondel-Cedarmas (p. 112).

Alle suggestioni occidentaliste del nazionalismo democratico polacco, seppur in chiave confessionale, fanno da contraltare l'anti-occidentalismo etnico e religioso dei movimenti panslavisti russi, oggetto dell'analisi di Joachim Diec, il cui limite è forse l'utilizzo quasi esclusivo di riferimenti e studi sul nazionalismo slavo ormai un po' datati. Una delle peculiarità del volume, però, è proprio il confronto tra nazionalismi e nazionalisti dell'Europa occidentale e orientale, come dimostra il contributo di Adriano Roccucci, che per riflettere sulla dialettica oriente-occidente nei processi di definizione dell'identità nazionale in Germania, Polonia, Ungheria e Russia, mette in luce l'importanza di una serie di elementi linguistici, culturali e religiosi per la definizione tanto delle identità nazionali che degli obiettivi stessi dei nazionalisti. Elementi che, insieme a una serie di fattori socio-economici, hanno fortemente influenzato anche le diverse idee d'Europa elaborate dal nazionalismo spagnolo, basco e catalano, come spiegato da Alfonso Botti in un interessante saggio che prende in considerazione le diverse evoluzioni politiche che il nazionalismo può subire sia a livello statale che sub-statale.

La seconda sezione del volume si concentra sul rapporto, stretto seppur non esclusivo, tra il nazionalismo della prima metà del XX secolo e i totalitarismi, in particolare quelli fascista e nazista. Marco Cuzzi, ad esempio, nel saggio di apertura ripercorre $\mathrm{i}$ diversi tentativi di creare un'Internazionale nera intorno al regime mussoliniano, che però più che rispondere a una reale tendenza universalista del fascismo rientrava in una strategia complessiva di «confronto diplomatico-ideologico» con la Francia, l'Urss e la Germania nazista (p. 136). Sia il fascismo che il nazismo, infatti, utilizzarono il nazionalismo e la retorica nazionalista per giustificare i propri progetti di supremazia militare e politica sul continente europeo. Nel caso tedesco, come sottolinea Monica Fioravanzo, molte delle prospettive elaborate dai nazionalisti tra le due guerre - il concetto geopolitico di spazio, la contrapposizione al modello anglosassone e a quello bolscevico, il rifiuto del parlamentarismo, la gerarchizzazione dell'ordine internazionale - furono poi recuperate e declinate in chiave razziale nel progetto di Nuovo Ordine Europeo nazionalsocialista. Il bel contributo di Fabio Ferraini analizza proprio una tra le più interessanti contraddizioni in cui il nazionalismo radicale cadde durante la seconda guerra mondiale in relazione al nuovo ordine nazionalsocialista; ripercorrendo la storia del nazionalismo norvegese, infatti, l'A. dimostra come la collaborazione con l'occupante tedesco abbia rappresentato un vero e proprio tradimento del principio fondamentale del nazionalismo stesso, che è proprio la difesa dell'indipendenza nazionale.

Un tema che ritroviamo, seppur da un punto di vista differente, anche nel contributo di Alberto Basciani sull'evoluzione dei nazionalismi rumeno e bulgaro tra le due guerre. Sulle diverse idee d'Europa elaborate dai nazionalismi statali e sub-statali in Spagna si concentra invece il contributo di Xosé M. Núnez Seixas, che si rivela di grande utilità per comprendere ancora una volta la capacità di ibridazione del nazionalismo e l'estrema eterogeneità dei movimenti nazionalisti. L'Europa, infatti, assume significati molto diversi se si guarda al nazionalismo spagnolo: un orizzonte di progresso per quello repubblicano e democratico, mentre nel campo tradizionalista e cattolico l'Europa non può che essere il baluardo della cristianità in chiave anti-comunista (p. 152); un tema utilizzato poi nel se- 
condo dopoguerra dal regime franchista per accreditarsi nel nuovo scenario internazionale. Di segno diametralmente opposto appare l'idea di Europa elaborata dai nazionalismi sub-statali, sinonimo di modernità e progresso, in confronto a una Spagna sempre più decadente e conservatrice, e che proprio alla dimensione europea guardavano già dopo la prima guerra mondiale in virtù del dibatto sulla protezione delle minoranze e sul diritto all'autodeterminazione dei popoli.

Il volume ha dunque il merito di riavviare una riflessione su un tema complesso per la storiografia italiana e soprattutto di porre l'accento sulle diverse idee di Europa che intellettuali, partiti e movimenti nazionalisti svilupparono in un periodo di grandi stravolgimenti politici, economici e sociali, sottolineando al contempo la capacità camaleontica del nazionalismo di contaminarsi e contaminare ideologie differenti, spesso anche antitetiche. Unico neo, forse, il poco spazio dedicato al rapporto tra nazionalisti ed Europa fuori dalla stringente cornice dei totalitarismi nazi-fascisti e dei regimi anti-democratici, che rappresenterebbe invece un campo d'indagine altrettanto interessante.

Paolo Perri*

\section{Lorenzo Kamel}

The Middle East from Empires to Sealed Identities

Edinburgh UP, Edinburgh 2019, pp. 288

Kamel, professore associato di Storia contemporanea all'Università di Torino, già autore di numerose pubblicazioni, tra cui Imperial Perceptions of Palestine. British Influence and Power in Late Ottoman Times (I.B. Tauris, 2015), in que- sto importante libro ribadisce l'idea, a lui cara, che ricostruire la storia del Medio Oriente sia una condizione necessaria per comprendere i cambiamenti avvenuti nella regione negli ultimi due decenni. Nello specifico, l'A. si occupa di un momento cruciale della storia mediorientale, la transizione dall'Impero ottomano agli Statinazione nati dopo la prima guerra mondiale, vale a dire il passaggio da identità «flessibili, sfaccettate e "con il trattino"» a «identità sigillate», a seguito del processo di «politicizzazione delle differenze etnico-religiose» (p. 5) messo in atto da una serie di attori, tanto regionali quanto internazionali. Furono soprattutto le due potenze coloniali che si spartirono il Medio Oriente dopo il crollo dell'Impero ottomano, Francia e Gran Bretagna, a portare avanti questo processo, assolutizzando differenze religiose fino ad allora poco rilevanti per costruire identità nazionali e politiche cui venivano attribuite caratteristiche di immutabilità e incompatibilità, così da rendere necessaria la presenza europea, presentata come l'unica garanzia della tenuta dei nuovi Stati. Dal punto di vista cronologico, l'A. si concentra sui decenni che vanno dagli anni '30 dell'800 agli anni '20 del '900, a partire cioè dalla conquista dell'Algeria da parte della Francia fino alla nascita dei mandati britannici (su Palestina, Transgiordania e Iraq) e francesi (su Libano e Siria).

Il volume, diviso in 7 capitoli, oltre a introduzione e conclusioni, è ricchissimo in quanto a fonti primarie e secondarie. Kamel riesce a intrecciare con sapienza una vastissima e multilingue bibliografia secondaria (dall'inglese al francese, all'ebraico, all'arabo) con una documentazione inedita impressionante in termini di quantità e qualità, proveniente da archivi consultati in Giordania, Israele, Palestina, Ci-

* Dipartimento di Scienze economiche e politiche, località Le Grand-Chemin 181, 11020 Saint-Christophe (Ao); p.perri@univda.it 
pro, Turchia, Grecia, Italia, Tunisia, Gran Bretagna e Stati Uniti. Il risultato è un libro molto approfondito, ben strutturato ed estremamente argomentato, che ha anche la qualità di essere scritto in maniera scorrevole e piacevole. Ma è anche un volume che credo possa essere definito "necessario", dal momento che fa comprendere la genesi del modo in cui molta parte dell'accademia, dei media e dell'opinione pubblica si accosta attualmente alle vicende mediorientali contemporanee - le guerre in Siria e Yemen, il conflitto israelo-palestinese, le tensioni in Libano e Iraq, l'inimicizia tra Iran e Arabia Saudita - operando un'operazione di "semplificazione", cioè una riduzione della complessità della realtà attraverso categorie note, spesso derivate dal passato (la cosiddetta «medievalizzazione» del Medio Oriente), sebbene del tutto errate e dunque fuorvianti.

Il primo capitolo serve come premessa metodologica, perché discute, decostruendoli, alcuni di quei concetti frequentemente impiegati per raccontare il Medio Oriente e che però, come detto, non permettono alcuna comprensione perché finiscono per restituire una realtà viziata dallo sguardo orientalista con cui abitualmente viene descritta la regione. Tra i termini decostruiti, ritengo valga la pena soffermarsi su quello di tribù, sovente utilizzato in ambito storico e giornalistico, finendo - consapevolmente o meno - per riprodurre un concetto tipicamente coloniale. Come bene scrive l'A., era funzionale alle potenze europee, tanto nel contesto mediorientale quanto in quello africano, fare in modo che le popolazioni colonizzate «pensassero a se stesse in termini di piccoli clan e tribù senza alcuna identità collettiva e più "elaborata"» (p. 24).

I successivi tre capitoli sono definiti da Kamel, in omaggio allo storico americano di origine palestinese Rashid Khalidi, il «primo», il «secondo» e il «terzo momento», durante i quali gli europei e, più in generale, l'Occidente trasformarono identità fluide e composite in elementi immutabili e insuperabili. Il «primo momento» - di cui si occupa il secondo capitolo - coincide con gli anni '30 dell'800, allorché la Francia occupò l'Algeria. Ma ancora più significativo fu l'incremento nel territorio dell'Impero ottomano della presenza di missionari e funzionari - si pensi ai vari consolati europei aperti in quegli anni. Questi due attori, infatti, lavorarono per aumentare le divisioni religiose ed etniche esistenti, sebbene non fossero molto sentite in quegli anni, introducendo identità di tipo nazionale per esacerbarle. Un esempio su tutti è la proposta nota come «doppio qaimaqato» (doppia prefettura), che le potenze europee convinsero l'Impero ottomano a introdurre in Libano: la creazione di un distretto cristiano a nord e di un'area drusa a sud, a partire dall'idea che le divisioni tra cristiani e drusi fossero ataviche e irreconciliabili, sebbene per secoli i due gruppi avessero convissuto in maniera sostanzialmente pacifica. Il «secondo momento», trattato nel terzo capitolo, è la stagione delle Tanzimat, le riforme volute dal sultano ottomano per porre fine alla crisi in cui l'Impero versava ormai da tempo. Negli anni tra il 1839, data del primo decreto, e il 1876, allorché venne promulgata la Costituzione (rimasta in vigore per soli due anni), proprio mentre l'Impero introduceva l'uguaglianza di tutti i cittadini di fronte alla legge indipendentemente dalla confessione religiosa, anche grazie agli attori ricordati, iniziarono a circolare in maniera sempre più marcata concetti tipicamente europei, quali patria e nazione, che vennero fatti propri dalle comunità non-musulmane dell'Impero. Se l'ottomanismo era la proposta di Istanbul perché tutta la popolazione dell'impero se ne sentisse parte in nome di un'identità laica e multiconfessionale, i cristiani lo rigettarono, ritenendolo «un progetto finalizzato a imporre l'islam sulle loro comunità e si rivolsero sempre più alle potenze europee per [ottenerne] sostegno» (p. 84). 
L'esempio più noto e calzante è chiaramente quello dei maroniti con la Francia.

Infine, il «terzo momento», affrontato nel quarto capitolo, è costituito da quanto accaduto tra il 1908, con la rivoluzione dei Giovani Turchi, e la prima guerra mondiale. È uno dei capitoli a mio avviso meglio riusciti, sia perché l'A. dimostra di avere uno sguardo ampio, mettendo in luce le connessioni esistenti tra vari eventi accaduti a livello regionale e globale, sia per il livello di approfondimento raggiunto grazie all'incrocio tra fonti primarie e secondarie, soprattutto in lingua araba. Con il processo di turchizzazione che Istanbul portò avanti - si pensi alla rimozione degli arabi dalle cariche più alte e l'imposizione del turco come la sola lingua negli uffici governativi - si registrò un boom di società segrete (ma anche aperte) composte da attivisti arabi che promuovevano una identità basata sull'appartenenza etnica. Con lo scoppio della Grande guerra, Francia e Gran Bretagna esasperarono questo processo, da un lato sostenendo la rivalità tra turchi e arabi in chiave bellica - la rivolta araba del 1916 rientrava proprio in questo disegno - e, dall'altro, trasformando le «identità religiose in categorie legali» (p. 104).

La Palestina, da questo punto di vista, fu il luogo privilegiato per mettere in pratica queste politiche e non è un caso che Kamel dedichi alla Terra Santa ampio spazio nel quarto e nel quinto capitolo, incentrato sulla genesi e le conseguenze della Dichiarazione Balfour. A partire dal 1917, allorché nel dicembre il generale Allenby entrò a Gerusalemme, i britannici si dedicarono a questo obiettivo, anche dal punto di vista urbano. Come ricorda A., «la comprensione dello spazio su base confessionale» (p. 104) è uno degli ambiti in cui la politicizzazione delle confessioni religiose fu più evidente, con il rafforzamento della divisione della Città vecchia in quattro quartieri su base confessionale, la deci- sione di cambiare i nomi delle strade per seguire tale criterio, e persino la distruzione della torre ottomana all'ingresso della città vecchia nei pressi della Porta di Giaffa, in quanto simbolo di un «impero moderno basato sul senso di una cittadinanza comune» (p. 105). E tale impostazione venne mantenuta durante il mandato, con la divisione della comunità araba palestinese tra cristiani e musulmani e il rafforzamento della dimensione religiosa a scapito di quella nazionale.

Il sesto capitolo, oltre a mettere in luce le profonde contraddizioni della Società delle Nazioni, incapace di adottare la clausola proposta dal Giappone per l'uguaglianza razziale, dimostra come il processo di politicizzazione delle identità religiose fosse giunto a compimento con il Trattato di Losanna del 1923, che sancì lo scambio di popolazioni greco-turche tra Turchia e Grecia, dando per scontato che gli individui di religione greco-ortodossa fossero parte della nazione greca, sebbene vivessero da secoli in Anatolia e parlassero ottomano e non greco, e gli individui musulmani fossero parte di quella turca.

Le conclusioni del volume permettono a Kamel di soffermarsi sull'attualità, letta con lo spessore e la consapevolezza della conoscenza storica. E il cuore del suo ragionamento ruota attorno alla supposta artificiosità dei paesi mediorientali, una delle (errate) vulgate storiografiche e giornalistiche più in voga in questi anni. L'A. dimostra come tanto la Palestina quanto l'Iraq non fossero solo realtà geografiche, ma anche territori percepiti dalle popolazioni che li abitavano come entità unitarie dove si era costruita la loro identità nazionale nel corso dei secoli.

In conclusione, si tratta di un volume molto ricco, approfondito e argomentato, che offre numerosi spunti di riflessione tanto per un'analisi storica, quanto di tipo politologico, e che aiuta il lettore a mettere in discussione una serie di retaggi orientalisti e coloniali tuttora utilizzati 
da commentatori e analisti per raccontare il Medio Oriente.

\section{Arturo Marzano*}

\section{Caner Yelbaşı}

The Circassians of Turkey. War, Violence and Nationalism from the Ottomans to Atatürk

I.B. Tauris, London 2019, pp. 264

Il volume ricostruisce il carattere e gli sviluppi delle attività politiche e paramilitari dei circassi, il più consistente gruppo etnico non turco residente entro i confini della moderna Repubblica di Turchia dopo quello curdo, in un arco temporale compreso tra il 1918, anno della resa ottomana al termine del primo conflitto mondiale, sancita dalla firma dell'armistizio di Mudros, e il 1938, anno della morte del primo presidente Mustafa Kemal Atatürk. Sulla base di un solido apparato di fonti primarie d'archivio e di letteratura secondaria Yelbaşı, addottoratosi presso la Soas di Londra, si propone di tracciare il dinamico andamento della vicenda storica dei circassi da sudditi fedeli, integrati entro le strutture dell'Impero ottomano, a «leali cittadini turchi» (p. 8), modellati dal titanico processo di costruzione nazionale intensificatosi in seguito alla proclamazione della Repubblica (1923), come sottolineato nell'introduzione.

Nel corso degli anni '60 del XIX secolo circa 500.000 circassi perirono e 800.000 trovarono rifugio entro i confini dell'Impero ottomano come risultante dell'invasione russa del Caucaso settentrionale, una cruenta opera di «sistematica distruzione e spoliazione» mirante a piegare la resistenza dei circassi «spingendoli gradualmente verso il Mar Nero, espellendoli, colonizzando e ripopolando i loro territori con cosacchi o popolazioni cristiane», come ben delineato da Fabio L. Grassi ( $A$ New Homeland: The Massacre of The Circassians, their Exodus to the Ottoman Empire and their Role in the Making of Modern Turkey, 2018, pp. 62-63). Una volta giunti nella loro nuova patria, i circassi vennero prontamente irreggimentati nelle fila dei reparti militari e degli ipertrofici apparati burocratici ottomani.

Già prima del massiccio esodo, si erano resi protagonisti di una lunga storia di interazione con le autorità imperiali, nella forma dello sfruttamento schiavistico di donne circasse rapite o vendute dalle proprie famiglie a esponenti dell'aristocrazia ottomana nel tentativo di inserirsi pienamente nei circuiti delle élite della Sublime Porta, intesa a reclutare la componente circassa per sopperire alla mancanza di uomini nell'esercito. Fenomeno, quest'ultimo, incentivato da una «warlike culture» (p. 23) che nell'immaginario collettivo caratterizzava le comunità circasse come diretta conseguenza di decenni di esili, spostamenti forzati e attività belliche. A partire dal 1913, sotto il "triumvirato" di Talaat Paşa, Enver Paşa e Cemal Paşa, i circassi presero attivamente parte a operazioni militari di stato nei ranghi dell'Organizzazione Speciale (Teşkilât-ı Mahsusa), operante in particolar modo in Tracia occidentale e nella regione di Marmara, definita da Erik J. Zürcher nel suo fondamentale Turkey: A Modern History (1993) «un laboratorio del movimento nazionale di resistenza che si sarebbe sviluppato in Anatolia dopo la Prima Guerra Mondiale» (p. 107).

Uno snodo centrale ai fini dell'analisi della presenza circassa nella storia della nascita della Turchia moderna è rappresentato dalla guerra greco-turca combattuta tra il 1919 e il 1922, nell'ambito della

* Dipartimento di Civiltà e forme del sapere, via Pasquale Paoli 15, 56126 Pisa; arturo. marzano@unipi.it 
quale i circassi si assestarono su fronti contrapposti: quello lealista, coagulatosi attorno alla potenza politica e simbolica del sultanato e del califfato di Istanbul, e quello nazionalista, affiliato al governo de facto di Ankara. Tale conflitto andò poi a riconfigurarsi come rivalità personale tra Anzavur Ahmed e Çerkes Ethem, due figure le cui vicende assurgono a paradigma delle contraddittorie dinamiche e degli alterni posizionamenti assunti dalle componenti circasse di Turchia in questa concitata fase. L'azione di Anzavur, tratteggiata nel secondo capitolo, fu indirizzata alla trasformazione della regione di Marmara in un centro del movimento anti-nazionalista, facendo leva sull'adesione all'Islam, la lealtà al sultano e le istanze d'opposizione al Comitato unione e progresso (Ittihat ve Terakki Cemiyeti), ritenuto responsabile delle disastrose condizioni umanitarie e sociali in cui la regione versava in conseguenza di una lunga sequenza di guerre e violenza sociale, dai due conflitti balcanici alla Grande guerra.

All'impossibilità di ricondurre all'ordine questo primo focolaio di dissenso si aggiunse l'impatto dei disordini promossi da notabili circassi locali ad Adapazar1-Düzce e Çapanoğlu (19191920), ampiamente trattati nel terzo e quarto capitolo, soppressi a seguito dell'intervento di Ethem, il quale si guadagnò, per un breve periodo, un posto d'onore nel pantheon nazionalista turco. Già impegnato nella creazione di una linea di resistenza all'occupazione greca composta da gruppi paramilitari in Anatolia occidentale, Ethem divenne ben presto un elemento di disturbo per il rafforzamento della leadership di Mustafa Kemal, anche in virtù degli stretti legami con Enver Paşa e la sua alternativa politica, di orientamento islamico socialista e filo-bolscevico, al nascente sistema di potere kemalista. I nazionalisti lo accusarono surrettiziamente di aver violato l'autorità dell'assemblea di Ankara, escludendolo dalle fila del proprio movimento e decretandone la diserzione a favore dell'esercito greco. Si trattò di un'evoluzione per molti versi simile a quella del circasso Çule İbrahim Hakkı Bey, in origine soggetto fedele al sultano, poi promotore della creazione di un'entità autonoma circassa nei territori occupati dai greci in Anatolia. Come analizzato nel quinto capitolo del volume, Hakk1 Bey si sarebbe distinto come ideologo di una «Circassianness (Çerkeslik) intesa come identità politica» (p. 105), espressione dei desideri di autoconservazione, protezione, riconoscimento dell'esistenza nazionale circassa e dei diritti a essa connessi, esplicitati durante il Congresso dei Circassi tenutosi a İzmir nell'ottobre 1921. La dichiarazione redatta in quell'occasione istituì un'analogia tra il movimento d'indipendenza arabo, che ricercò l'appoggio degli Alleati contro l'oppressione ottomana durante la prima guerra mondiale, e il movimento circasso, deciso a legarsi politicamente ai greci per smarcarsi dall'egemonia di Istanbul.

Nel 1922-23, in seguito alla conclusione della guerra greco-turca, l'affermazione, seppur molto limitata, di una consapevole e organica identità politica circassa e l'intensificarsi dell'azione di banditi e gruppi armati circassi, trasformarono questa comunità nell'unica reale minaccia al processo di legittimazione dell'establishment repubblicano turco. Questo spinse il governo di Ankara ad adottare le prime contromisure e ritorsioni descritte nel sesto capitolo. In principio, fu attuata la deportazione verso l'Anatolia centrale e orientale di circa 3.500-4.000 individui residenti in 14 villaggi a maggioranza circassa dei distretti di Gönen e Manyas. Il provvedimento punitivo fu condotto in modo del tutto arbitrario e secondo logiche categoriali di sicurezza collettiva, senza differenziazione alcuna tra i circassi effettivamente coinvolti in attività antigovernative e quelli a esse estranei. Seguì 
l'inclusione di 86 individui di etnia circassa nella lista delle 150 personae non gratae (yüzellilikler) da escludere dai benefici dell'amnistia promulgata nell'aprile 1924. Condannate in forza della Legge per alto tradimento dalle numerose Corti militari sorte all'ombra della neonata Repubblica, tali persone furono private della cittadinanza turca e spogliate di beni e proprietà. I provvedimenti miravano alla distruzione economica e all'assimilazione etnica delle comunità circasse attraverso l'indebolimento dei legami comunitari e il progressivo annientamento delle loro rivendicazioni culturali.

In tal senso, come puntualmente documentato da Yelbaşı, i circassi furono fortemente oppressi nel primo periodo repubblicano in quanto considerati «un retaggio del multiculturale, multilinguistico e multietnico passato ottomano [...] e un ostacolo alla creazione di una nazione omogenea» (p. 180). In accordo con una logica nazionalista prettamente occidentale, le comunità musulmane di Turchia, compresa quella circassa, «realizzarono di non essere più parte della "maggioranza musulmana e ottomana", ma - inderogabilmente - della nazione turca» (Grassi, 2018, p. 131). Possiamo inquadrare questo fenomeno nella più ampia cornice del progetto di turchizzazione (türkleştirme) "dall'alto" di masse di individui di etnia non turca, considerati dei «turchi in potenza», secondo l'efficace definizione di Soner Çağaptay (Islam, Secularism and Nationalism in Modern Turkey: Who is a Turk?, 2005, p. 78).

Nell'ottica della formazione di uno stato nazione secolare, moderno e centralizzato, il concetto di patria diventò un «deposito di memorie e legami storici», come sottolineato da Anthony J. Smith (National Identity, 1991, p. 19): uno spazio esclusivo dal quale estrarre i corpi estranei, la «religione, la tradizione e le periferie» (p. 160) linguistiche e culturali. Ciò, nel caso turco, sarebbe avvenuto entro i confini di uno spazio geografico non coincidente con il luogo di origine ultima di gran parte delle élite nazionaliste. Lo spazio geografico doveva quindi essere storicamente (ri) costruito come tale (Smith, 1991, p. 19; Zürcher, 1993, p. 106). Il processo di edificazione nazionale in Turchia penalizzò pesantemente i circassi, che persero i privilegi posizionali precedentemente conquistati nelle strutture politiche ottomane ed entro l'élite sociale stambuliota. Emblematica e paradossale è la vicenda della reginetta di bellezza Keriman Halis, originaria di uno dei villaggi interessati dalle deportazioni del 1923, eletta Miss Mondo nel 1932 e innalzata a simbolo della moderna donna di etnia turca, consapevole ed emancipata, attraverso una massiccia campagna di propaganda sui maggiori quotidiani del paese, prima di essere esclusa da celebrazioni ed eventi pubblici a seguito della diffusione di notizie circa la sua vera identità. Nonostante ciò, a detta dell'A., l'atteggiamento dello Stato turco rispetto ai circassi rimase tendenzialmente improntato a una ambivalenza di fondo, che portò il governo a proibire l'espressione della loro identità e l'uso della lingua negli spazi pubblici, ma anche ad accogliere nel corso degli anni ' 20 e in funzione anti-sovietica i rifugiati circassi provenienti dal Caucaso settentrionale.

Nel periodo compreso tra il 1946, anno delle prime elezioni multipartitiche in Turchia, e il 1950, anno del trionfo elettorale del Partito democratico, prese avvio un graduale processo di riconciliazione tra la componente circassa e lo Stato, corroborato dalla cooptazione di numerosi circassi nei dipartimenti di polizia e negli apparati di sicurezza interna, e simbolicamente suggellato dall'apertura dell'Associazione di mutuo soccorso "Mano Amica" (Dosteli Yardımlaşma Cemiyeti), prima realtà culturale circassa del paese (Grassi, 2018, p. 133). Lo stemperamento dell'immagine negativa e dei sospetti articolatisi nella società turca del tempo attorno a questa minoranza fu reso possibile, 
oltre che dai processi di urbanizzazione e di crescente interazione delle minoranze con le strutture statali, anche dalla presenza di esponenti di etnia circassa ai vertici del Partito Popolare Repubblicano di Atatürk (tra i quali 3 primi ministri: Ali Fethi Okyar, originario dell'allora Macedonia ottomana, premier dal 1924 al 1925, Ahmet Fikri Tüzer, nato nell'odierna Bulgaria, in carica per pochi giorni nel 1942, e Recep Peker, al potere tra il 1946 e il 1947), e dal contesto della guerra fredda, che ricompattò lo Stato e i circassi contro il comune nemico sovietico.

Nella conclusione della sua importante ricerca, l'A. indaga i conflitti di memoria interni alla comunità circassa, confluiti, almeno parzialmente, nell'elaborazione di quella che viene definita una «identità circassa immaginata» (p. 183), alimentata dalla credenza nel ruolo fondamentale giocato dai circassi di Turchia nella costruzione della Repubblica, in virtù dell'operato di Çerkes Ethem, in prima linea nella repressione dei disordini anti-nazionalisti, e dalla presenza di soldati e burocrati circassi nelle fila del movimento nazionalista turco. Si tratta tuttavia di una memoria parziale, frutto di una lettura politicamente interessata del passato e basata sull'estromissione di eventi cruciali, quali l'espulsione di Ethem dai circoli nazionalisti e il dato, fondamentale quanto scomodo, relativo all'adesione della grande maggioranza di circassi alle politiche del sultano. Con un atto di coraggio intellettuale ancora più apprezzabile alla luce della politica della storia nella Turchia odierna, lo storico turco mette in guardia il lettore dai pericoli di una storia artatamente costruita, slegata dalla realtà o insensibile a essa, tesa a presentare singoli fotogrammi disconnessi dal contesto generale come immagini generalizzanti e autoevidenti.

Vanni Rosini*

\section{Fabio Turato}

La Germania populista. Voto e protesta di Alternative für Deutschland

Epoké, Novi Ligure 2019, pp. 210

Il volume di Turato non si propone come ricerca a carattere storiografico. Nondimeno, ha l'assoluto pregio di sollevare la necessità di una storicizzazione di un fenomeno multidisciplinare e complesso qual è la destra populista tedesca, oltre che per la qualità dello studio in sé. Scopo dell'A. è quello di ricostruire e approfondire le vicende che hanno portato all'ascesa del partito di Alternativa per la Germania (Afd), con un occhio di riguardo per i cambiamenti nel rapporto tra la politica e i cittadini «su temi spesso trascurati dai partiti tradizionali» (p. 13): idea di Volk (popolo), confini e identità nazionale, globalizzazione. Pur non trattandosi, dunque, di un lavoro a carattere storiografico sui nazionalismi, il volume intercetta in modo pressoché naturale molti contenuti di assoluto interesse e pertinenza per lo storico e ricercatore.

Il caso di Pegida (acronimo di «Europei patriottici contro l'islamizzazione dell'Occidente»), movimento fondato a Dresda (Sassonia) nel 2014 ed espressione extraparlamentare della destra xenofoba e vicina agli ambienti neonazisti, introduce il lettore a tematiche e a concetti sui quali si avrà modo di tornare in più occasioni nei capitoli successivi. Da qui l'opportunità colta dall'A. di illustrare alcune caratteristiche peculiari e stigmatizzanti del populismo in Germania: l'attecchimento nelle zone orientali del paese rispetto a quelle occidentali, tema particolarmente attuale e sensibile sia in campo storico-scientifico (M. Ponso, 2015) che per l'opinione pubblica tedesca; il rapporto tra la politica extraparlamentare e i partiti tradizionali (Cdu,

* Università di Firenze, piazza S. Marco 4, 50121 Firenze; vanni.rosini@stud.unifi.it 
Spd, Die Grüne); il riciclaggio di motivi ed espedienti narrativi peculiari del neo-nazionalismo e della storia recente del paese. Tra questi ultimi spiccano il tema dell'identità nazionale, lo scontro con la minoranza e cultura islamica (i temi dell'immigrazione e dell'integrazione) e l'euroscetticismo. Qui vale la pena ricordare il ritorno alla ribalta di slogan anticomunisti come «Wir sind das Volk», frase divenuta celebre durante le manifestazioni del 1989 contro il regime comunista della Sed (Partito socialista unificato di Germania), oggi espressione inflazionata dagli attivisti di Pegida. Tenendo fede a quest'impostazione, l'A. prosegue illustrando l'ascesa di Afd nello scenario politico tedesco: dalla formazione al consolidamento dei quadri dirigenti, dai primi successi alle elezioni nei Lander federali del 2016 (p. 63) alle più recenti elezioni europee del 2019 (p. 165), nelle quali gli Alternativi si sono imposti come il quarto partito tedesco $(11 \%,+4 \%$ rispetto al 2014).

Lettura fortemente consigliata per gli appassionati del contesto tedesco, La Germania populista riesce indubbiamente nel suo scopo di fornire un'inquadratura esaustiva di Alternative für Deutschland. Ne deriva l'immagine di un movimento politico effettivamente alternativ, dotato di una struttura interna complessa e con una narrazione multilivello, capace di adattare il proprio messaggio politico ai diversi Länder e di realizzare proposte spesso fin troppo lontane l'una dall'altra a seconda dei diversi contesti regionali ed elettorati di riferimento. Un dato, quest'ultimo, particolarmente evidente nelle aree della ex-Ddr, in cui gli «alternativi» riescono a imporsi anche grazie a una maggiore sensibilità alle loro proposte da parte di quel tessuto sociale. Riferimenti al «popolo tedesco originario» (p. 173), antinomia tra identità nazionale e una classe dirigente «globalizzata» e ormai facente «parte di una società distaccata, cittadina del mondo» (p. 126) sono messaggi che riscuotono particolare successo in una realtà contrassegnata da una forte omogeneità culturale: tema pressoché ignorato e con il quale la Repubblica federale non si è mai confrontata con politiche strutturali in trent'anni dal crollo del Muro (1989-2019).

La struttura del libro e lo stile narrativo dell'A. costituiscono, in ultima analisi, sia il pregio che il difetto di quest'opera. Da un lato, la distribuzione dei contenuti nei vari capitoli e la ricchezza dei dati messi a disposizione (apprezzabile, soprattutto, la presenza di numerose cartine e tabelle) fanno la fortuna del ricercatore. Questo rigore analitico, tuttavia, riserva spesso sorprese molto spiacevoli alla lettura. In particolare, la mistura di note a piè di pagina e di riferimenti bibliografici nel testo, unita a un'eccessiva uniformità dei tempi verbali al presente possono creare disorientamento, specie nel caso in cui si rendano necessari riferimenti al passato. Stesso discorso per quanto concerne la sovrabbondanza di contenuti ridondanti al netto di altri che vengono appena accennati: la disparità del voto verso Afd tra le zone orientali e occidentali del paese, ad esempio, non dà il via a una riflessione soddisfacente sulle politiche culturali di Alternative für Deutschland o sulla posizione dei populismi tedeschi di oggi rispetto all'eredità storica delle due Germanie divise.

Menzione d'onore per la copertina, che riprende un meme utilizzato dagli Alternativi in campagna elettorale: un porcellino salvadanaio con l'espressione triste guarda lo spettatore, lasciando intendere di essere ormai vuoto a causa dei troppi fondi che la Germania destina all'Unione Europea. Edoardo Lombardi*

* Istituto storico della Resistenza e dell'età contemporanea di Pistoia, viale Petrocchi Policarpo 159, 51100 Pistoia; edo.lombardi@outlook.it 